\title{
Short Communication: DNA extraction from stored wood of Falcataria moluccana suitable for barcoding analysis
}

\author{
HASYYATI SHABRINA ${ }^{1, \vartheta}$, ULFAH J. SIREGAR ${ }^{2}$, DEDEN D. MATRA ${ }^{3}$, KOICHI KAMIYA ${ }^{4}$, \\ ISKANDAR Z. SIREGAR ${ }^{2, \vee \varphi}$ \\ ${ }^{1}$ Tropical Silviculture Program, Department of Silviculture, Faculty of Forestry, Institut Pertanian Bogor. Jl. Ulin, Dramaga Campus, Bogor 16680, West \\ Java, Indonesia. Tel/fax +62 2518626806 , `email: hasyyati_shabrina@apps.ipb.ac.id \\ ${ }^{2}$ Department of Silviculture, Faculty of Forestry, Institut Pertanian Bogor. Jl. Ulin, Dramaga Campus, Bogor 16680, West Java, Indonesia. \\ Tel/fax +62 251 8626806, ^email: siregar@apps.ipb.ac.id, izsiregar@yahoo.com \\ ${ }^{3}$ Department of Agronomy and Horticulture, Faculty of Agriculture, Institut Pertanian Bogor. J1. Meranti, Dramaga Campus, Bogor, West Java, Indonesia \\ ${ }^{4}$ Forest Resource Department, Faculty of Agriculture, Ehime University, 3-5-7 Tarumi, Matsuyama, Ehime Prefecture, Japan
}

Manuscript received: 24 February 2019. Revision accepted: 29 May 2019.

\begin{abstract}
Shabrina H, Siregar UJ, Matra DD, Kamiya D, Siregar IZ. 2019. Short Communication: DNA extraction from stored wood of Falcataria moluccana suitable for barcoding analysis. Biodiversitas 20: 1748-1752. Sengon or Falcataria moluccana (Miq.) Barneby \& J.W.Grimes is the main crop in community tree plantations in Java, Indonesia, favored because of its fast-growing property and the promising economic return. The wood itself is mostly used for light construction, furniture, plywood, packing materials, and recently as feedstock for bioenergy. Sometimes the wood is used as DNA source for example in the wood identification analysis. However, extracting DNA from woods is considered difficult due particularly to very small quantities of DNA. The objective of this research was to optimize and modify the common CTAB protocols to extract DNA from Sengon wood without liquid nitrogen which sometimes unavailable in some laboratories. The extracted DNA was quantified with nanophotometer and gel visualization and amplified with primer coding $p s b \mathrm{~A}-t r n \mathrm{H}$ intergenic spacer for testing. The highest concentration of DNA extracted was from $100 \mathrm{mg}$ of wood stored for 24 hours in $-30{ }^{\circ} \mathrm{C}(257.80 \mathrm{ng} / \mu \mathrm{L}$ or $14.18 \mu \mathrm{g}$ in total $)$ and even the lowest concentration produced by this method able to produce sufficient amount of PCR product for sequencing. Compared with results from $200 \mathrm{mg}$ samples and longer freezing time (72 hours) and extraction using liquid nitrogen, this method considered gave the best results.
\end{abstract}

Keywords: DNA isolation, Sengon, liquid nitrogen, wood

\section{INTRODUCTION}

Falcataria moluccana (Miq.) Barneby \& J.W.Grimes (Indonesian: Sengon, Sundanese: Jeunjing, International name: Batai) is the main crop in the private land tree plantations (PLTPs) in South East Asia, especially in Java, Indonesia. It comes as second most source of log from West Java in 2015 (BPS 2015). Sengon was a native species in Moluccas and Papua and believed spread widely across Indonesia after 1871 (Corryanti and Novitasari 2015). The increasing number of Sengon plantation especially in Java have contributed to elevate community income (Siregar et al. 2007) and short time investment return within four years (Alipon et al. 2016). Sengon plantation in Indonesia was considered as new source of wood, as now we are facing the scarcity of wood from natural forest. The market of Sengon plantation is quite prospective, of which a Sengon with $20 \mathrm{~cm}$ in diameter is priced about Rp 500000 (US\$ 38), or equally Rp 1200 000 (US\$ 92) per $\mathrm{m}^{3}$. The wood industries using sengon or batai wood are also growing fast and start entering international markets. The wood itself is mostly used in light construction, furniture, plywood, packing materials, and recently as one of the woods used as feedstock in bioenergy.

Wood is sometimes used as the DNA source when the fresh tissues are not available. Wood is also useful in studies like transcriptomics, wood identification and DNA based timber tracking. However, DNA extraction from hard tissue like wood that had been stored for particular length is considered difficult due degraded nature of the wood and contamination from wood extractives (Jiao et al. 2012). It is difficult primarily because of only small amounts of DNA present in the xylem of even living trees (Abe et al. 2011).

Sometimes DNA extraction kit used to extract the DNA to obtain better results but somehow it was more expensive and difficult to automate (Bashalkhanov and Pajora 2008). Those situations lead to the necessity to optimize extraction method for stored wood samples with common methods such as CTAB or SDS.

There are many factors that lead to DNA degradation during the isolation process. One of the main problems encountered is due to endonuclease activities that damaging the DNA (Weising et al. 2005). The mechanical treatments applied to disrupt wood tissue also can cause overheating, leading to irreversible DNA degradation 
(Rachmayanti et al. 2006; Hamalton 2016). One attempt to inhibit endonuclease activities and overheating is using liquid nitrogen during the disrupting process. However, in some laboratory, the availability of liquid nitrogen is often limited.

The objectives of this study were to optimize a rapid DNA isolation method of sengon wood samples stored for 1 year, and then testing it whether the DNA is sufficient for $\mathrm{PCR}$ application by amplifying using psbA-trn $\mathrm{H}$ intergenic spacer primer.

\section{MATERIALS AND METHODS}

\section{Sample collections}

Samples were collected from trees in plantations in Bogor and Ciamis districts, West Java, Indonesia. The wood tissues used in this research was the sapwood near the bark. The wood tissues were collected from the standing tree by slicing the outer part of the sapwood using a sharp knife. The depth of the wood collected was around 2-3 cm. The wood samples were then cleaned by spraying alcohol before storing it in a plastic bag filled with silica gel and chilled in an ice box during transportation to the lab. The wood samples were then sliced into size $2-5 \mathrm{~mm}$ using hand scalpel and kept frozen in- $20{ }^{\circ} \mathrm{C}$ in a freezer for a year.

\section{DNA isolation}

DNA was isolated using Cetyl Trimethyl Ammonium Bromide (CTAB) method developed by Doyle (1991) with some modification. In this research, we also tried to find out the optimum amount of wood sample to obtain the best result. Two sample weights, i.e., 0.1 and $0.2 \mathrm{~g}$ were placed in screw-capped extraction tubes along with the metal beads. The samples in the tubes were then stored at $-30{ }^{\circ} \mathrm{C}$ for either 24 or 72 hours. Later the samples were ground using Qiagen TissueLyser II with $2 \mathrm{~mm}$ beads for 2 minutes, 5 times at $30 \mathrm{~Hz}$. Grinding process using liquid nitrogen was also conducted as control. Powdered samples were transferred to $2 \mathrm{ml}$ tube filled with $1 \mathrm{~mL}$ extraction buffer (1M Tris-HCl, 5M NaCl, 0.5 M EDTA, 10\% w/v CTAB, $1 \% \mathrm{w} / \mathrm{v} \mathrm{PVP})$ and $5 \mu \mathrm{L} \beta$-mercaptoethanol and incubated in heat block for 2 hours at $60{ }^{\circ} \mathrm{C}$. Samples were centrifuged for 5 minutes at $15000 \mathrm{rpm}$ and the supernatant was transferred to other tubes. Chloroform: isoamyl alcohol (24: 1) was added and mixed before centrifuged for 5 minutes at $15000 \mathrm{rpm}$, after which the supernatants were transferred to other tubes, and this process was repeated until we get the clear supernatant. The final supernatants were transferred to $1.5 \mathrm{~mL}$ tubes and added equal volume of isopropanol with the supernatant, and $3 \mathrm{M} \mathrm{NaCl} 0.25 \mathrm{x}$ supernatant volumes. The samples were incubated at $-30{ }^{\circ} \mathrm{C}$ for 1 hour and then centrifuged for 5 minutes at $15000 \mathrm{rpm}$. The watery parts were discarded carefully so the pellet remained on the tubes and air dried. The pellets were diluted by adding $55 \mu \mathrm{L}$ of TE buffer and vortexed.

The quality and quantity of DNA were checked by running a $3 \mu \mathrm{L}$ DNA samples mixed with loading dye in electrophoresis separation using $0.8 \%$ agarose gel, for 15 minutes, at $100 \mathrm{~V}$. The agarose was then stained in $\mathrm{EtBr}$ solution for 30 minutes and visualized under UV light and photographed. The DNA analyzed using Implen Nanophotometer NP80 (Implen GmbH, Munich, Germany) to quantify the results.

\section{DNA amplification}

The primers used in this process were $\operatorname{trn} \mathrm{H}$ (GUG) (5'ACTGCCTTGATCCACTTGGC-3') and psbA (5'GCAAGCTCCATCTACAAATGG-3') intergenic spacer (Hamilton 1999). The amplification reaction contained GoTaq Mastermix $10 \mu \mathrm{L}, 1 \mu \mathrm{L}$ of each primer, $1 \mu \mathrm{L}$ of DNA template, and water added up to $20 \mu \mathrm{L}$. The amplifications were carried out using the ABI thermal cycler 9700 with the following protocol: initial denaturation for 2 minutes at $95^{\circ} \mathrm{C}$; followed by 35 cycles of denaturation for 1 minute at $95^{\circ} \mathrm{C}$, annealing for 1 minute at $55^{\circ} \mathrm{C}$, and extension for $1 \mathrm{~min}$ at $72^{\circ} \mathrm{C}$; then continued in a final extension step for 10 minutes at $72^{\circ} \mathrm{C}$. The amplified products were separated on $2.0 \%$ agarose gels followed by Ethidium Bromide staining and visualization under UV light.

\section{RESULTS AND DISCUSSION}

\section{DNA isolation}

Samples were collected from sapwood tissue close to the bark considering the convenience of collection process. Another reason for picking the sapwood was the amount of DNA in the tissue is considered higher than in the deeper part of the wood (De Filippis and Magel 1998). The sapwood near barks also had the thinnest cell wall about $10.55 \mu \mathrm{M}$ (Hussin et al. 2014), which make the grinding process easier to produce fine powder. During the wood tissue extraction process, any mucous solution was not formed in the supernatant after the chloroform purification, unlike extraction process from leaves tissue (Shabrina and Siregar 2015). That means the amount of polysaccharides produced during the extraction process was much lower than from leave tissues.

The amount of DNA extracted from $0.1 \mathrm{~g}$ and $0.2 \mathrm{~g}$ samples did not differ much. This study showed that the more amount of samples did not always result in more DNA quantity. Study by Fatima et al. (2018) showed that the optimum ratio of samples and extraction buffer was 500 $\mathrm{mg}$ : $5 \mathrm{~mL}$, whereas in our case a ratio of $100 \mathrm{mg}$ : $1 \mathrm{~mL}$ was the optimum ratio. The additional step for protein removal with chloroform and isoamyl alcohol was performed as mentioned by Verbylaite et al. (2010) to obtain more purity in the product. However, there was still high amount of contaminant shown in the agarose gel as smears due to the absence of PVP and RNAse addition in the lysis process. The $\mathrm{A}_{260} / \mathrm{A}_{280}$ ratio showed that the variation happened in all methods used. However, the method with liquid nitrogen gave the lowest score of $\mathrm{A}_{260} / \mathrm{A}_{280}$ ratio. The $\mathrm{A}_{260} / \mathrm{A}_{280}$ ratio score lower than 1.8 showed that there was the possibility of protein contamination and the score higher than 2.0 indicated that there was another contaminant such RNA or salt (Figure 1; Table 1). 
Amplification with $p s b \mathrm{~A}-\operatorname{trn} \mathrm{H}$ intergenic spacer region

The successfully extracted DNA was then processed further by PCR amplification using psbA-trn $\mathrm{H}$ intergenic spacer primer. The amplification resulted in single, clear fragment across samples (Figure 2) that were sufficient for sequencing process. The rate of successful amplification was $100 \%$ with the fragment sizes about $500 \mathrm{bp}$ in length. The lower concentration of template, the produced band became weaker.

\section{Discussion}

Freezing the samples at-20 ${ }^{\circ} \mathrm{C}$ resulted in clear supernatant and no sign of browning which indicated that the oxidation process of DNA was inhibited during extraction process. Sahu et al. (2012) stated that-20 ${ }^{\circ} \mathrm{C}$ worked in preventing damage to the samples, and the cooler the temperature will result in lower degradation. Another sample with 72 hours freezing time prior to grinding resulted in similar quantity and quality of DNA with those of 24 hours treatments. Considering the length of time required to obtain good quality of DNA, freezing the sample for 24 hours is enough and efficient because the quantity of DNA produced did not differ either. The quantity of DNA produced did not differ either. Ferdous et al. (2012) stated that without liquid nitrogen in the grinding process reduced the isolation cost. Membrane column sometimes used to purify the DNA but it could lead to decrease in DNA quantity (Shabrina and Siregar 2015).

Table 1 The nanophotometer result of DNA extracted from all methods used

\begin{tabular}{|c|c|c|c|c|}
\hline $\begin{array}{l}\text { Starting } \\
\text { material }\end{array}$ & $\begin{array}{l}\text { Freezing } \\
\text { method }\end{array}$ & $\begin{array}{l}\text { Disrupting } \\
\text { method }\end{array}$ & $\begin{array}{c}\text { Maximum } \\
\text { DNA yield } \\
(\mathrm{ng} / \mu \mathrm{L})\end{array}$ & $\begin{array}{c}\mathbf{A}_{260} / \mathbf{A}_{280} \\
\text { ratio }\end{array}$ \\
\hline $100 \mathrm{mg}$ & $24 \mathrm{hrs} ;-30^{\circ} \mathrm{C}$ & TissueLyser & 257.80 & $1.87-2.25$ \\
\hline $200 \mathrm{mg}$ & $24 \mathrm{hrs} ;-30^{\circ} \mathrm{C}$ & TissueLyser & 140.45 & $1.89-2.86$ \\
\hline $100 \mathrm{mg}$ & $72 \mathrm{hrs} ;-30^{\circ} \mathrm{C}$ & TissueLyser & 214.35 & $1.91-4.38$ \\
\hline $200 \mathrm{mg}$ & $\begin{array}{l}\text { Liquid } \\
\text { nitrogen }\end{array}$ & Hand grinding & 174.10 & $1.48-2.84$ \\
\hline
\end{tabular}

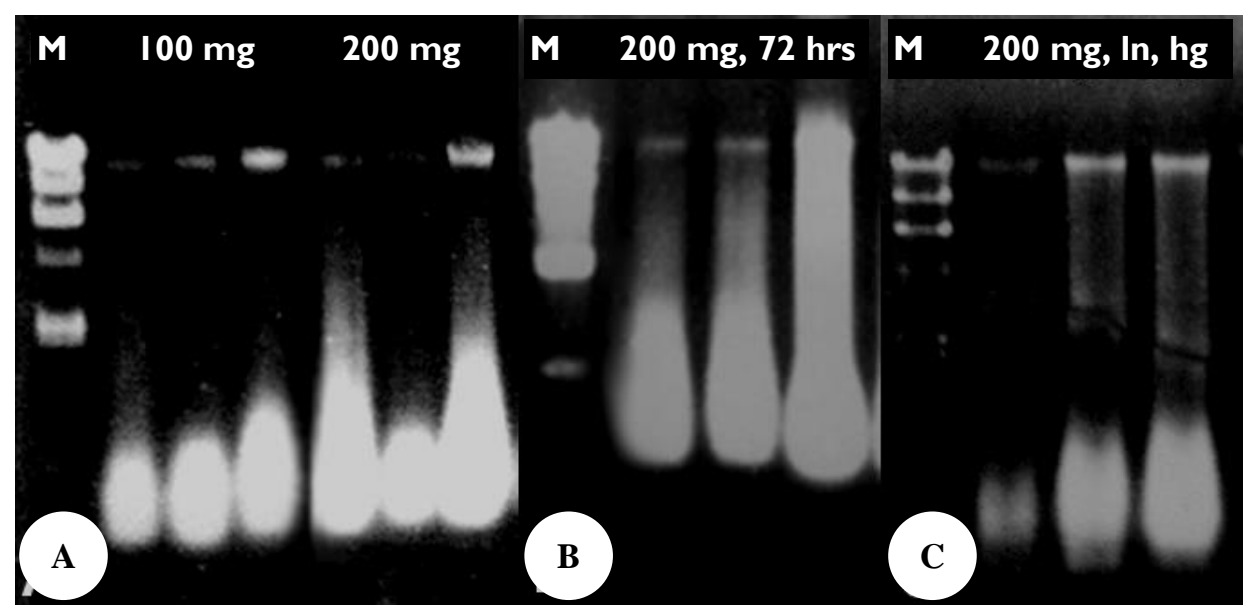

Figure 1. DNA extracted from A) 0.1 (lane 2-4) and 0.2 (lane 5-7) g tissue, frozen 24 hours, B) $0.1 \mathrm{~g}$ tissue, frozen 72 hours, and C) 0.2 $\mathrm{g}$ tissue with liquid nitrogen and grind using mortar. M: $\kappa$ Hind III

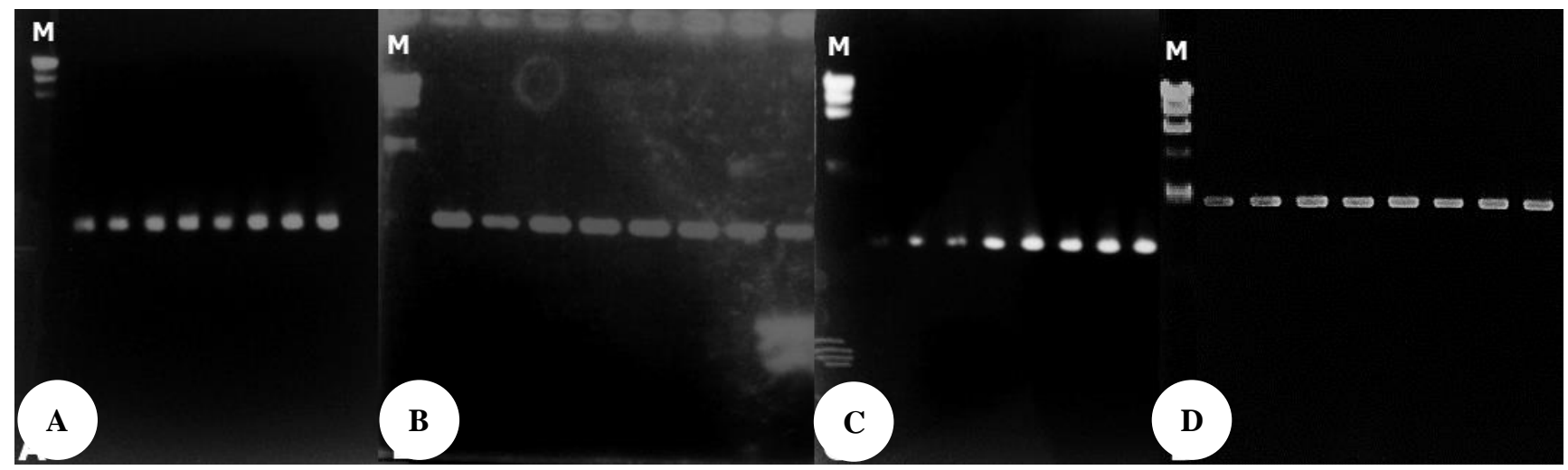

Figure 2. The amplification results using $p s b \mathrm{~A}-\operatorname{trn} \mathrm{H}$ intergenic spacer primer with DNA from previous extraction methods as template: A) $100 \mathrm{mg}$ frozen for 24 hours in $30^{\circ} \mathrm{C}$; B) $200 \mathrm{mg}$ frozen for 24 hours in $30^{\circ} \mathrm{C}$; C) $100 \mathrm{mg}$ frozen for 72 hours in $30{ }^{\circ} \mathrm{C}$; D) $200 \mathrm{mg}$ frozen with liquid nitrogen; M: $1 \mathrm{~kb}$ DNA ladder. 
Rachmayanti et al. (2009) used unprocessed Dipterocarpaceae wood stored for 1-4 years and was still able to achieve $87.85 \%$ success of amplification rate using $\operatorname{trn} \mathrm{F}, t r n \mathrm{~L}$, and $c c m p 2$ region from the chloroplast genome as primers. Verbylaite et al. (2010) also showed that the DNA obtained from wood was around 1/5 concentration of the DNA isolated from leaves but still able to produce clear band when amplified with trnLUAAF - trnF GAA primers. The success of the amplification process was also reported in Piccolo et al. (2012) that amplify SCAR markers, ITS region, and 16S rRNA gene from DNA isolated from grapevine plants without liquid nitrogen.

There were a lot of variations regarding the minimum amount of DNA required as PCR templates. A study by Fazekas et al. (2010) in improving sequence quality from PCR products containing long mononucleotide repeats, they used $20 \mathrm{ng}$ DNA as template for $20 \mu \mathrm{L}$ PCR reaction. However, in our case, as small as $1.8 \mathrm{ng} / \mu \mathrm{L}$ DNA able produced sufficient band for sequencing process and gave good sequence results (data unpublished). In other cases such as PCR with arbitrary primers like RAPD, a study by Stiles et al. (1993) used $15 \mathrm{ng}$ DNA as template so the bands became clear for scoring. Another study by Porebski et al. (1997) modified the CTAB DNA extraction process and as low as 5 ng DNA gave clear result in amplifying DNA from various species that contain high polyphenols and polysaccharides with RAPD primers. Welsh and McClelland (1990) also stated that as low as $30 \mathrm{pg}$ in 10 $\mu \mathrm{L}$ PCR reaction with arbitrary primers gave same band pattern with higher DNA concentration in PCR. Therefore, even if some contaminants like protein or other compound found in the DNA extracted, if the DNA diluted enough so the contaminant will not interfere the PCR process the sufficient band(s) will appear. Study by Shi and Panthee (2017) showed that even diluting DNA from 50 to $0.2 \mathrm{ng}$ (200 folds) able to amplify $\mathrm{Ph}-3$ gene marker in various plants leaves.

In conclusion, this modified CTAB extraction method using $100 \mathrm{mg}$ samples that frozen for 24 hours was the best to extract the DNA from sengon wood in a low-cost and time efficient process. We hope this method will able to reduce the DNA extraction cost and time consumed for laboratory works for molecular analysis, not only for sengon, but also for other woods from fast-growing and polysaccharides and polyphenols rich plants.

\section{ACKNOWLEDGEMENTS}

Special thanks are given to the Ministry of Research, Technology, and Higher Education (RISTEKDIKTI) of Indonesia for giving financial support with PMDSU grant. We also want to thank BKP5K Bogor District and BPTA Ministry of Environment and Forestry, Ciamis District, for access to the materials used in this study and Laboratory of Forest Genetics, Ehime University, Japan for hosting the research study. This research partially funded by PMDSU Scheme KEMENRISTEKDIKTI and USAID through the SHERA Program-Centre for Development of Sustainable
Region (CDSR). In year 2017-2021, CDSR is led by Center for Energy Studies, Gadjah Mada University, Yogyakarta, Indonesia.

\section{REFERENCES}

Abe H, Watanabe U, Yoshida K, Kuroda K, Zhang C. 2011. Changes in organelle and DNA quality, quantity, and distribution in the wood of Cryptomeria japonica over long-term storage. IAWA J 32 (2): 263272.

Alipon MA, Alcachupas PL, Bondad EO, Cortiguerra EC. 2016. Assessing the utilization of Falcata [Falcataria moluccana (Miq.) Barneby \& J. W. Grimes] for Lumber Production. Philippine J Sci 145 (3): 225-235

Bashalkanov S, Rajora OP. 2008. Protocol: A high-throughput DNA extraction system suitable for conifers. Plant Methods 4 (1): 20-25. DOI: $10.1186 / 1746-4811-4-20$

Corryanti, Novitasari D. 2015. Sengon and Gall Rust Disease. Perhutani, Cepu. [Indonesian]

Doyle JJ. 1991. DNA protocols for plants. pp. 283-293. In: Hewitt G, Johnson AWB, Young JPW (eds.). Molecular Techniques in Taxonomy. NATO ASI Series H, Cell Biol 57: 283-293.

Fatima T, Srivastava A, Hanur VS, Rao MS. An effective wood DNA extraction protocol for three economic important timber species of India. Am J Plant Sci 9: 139-149.

Fazekas AJ, Steeves R, Newmaster SG. 2010. Improving sequencing quality from PCR products containing long mononucleotide repeats. Biotechniques 48 (4): 277-283.

Ferdous J, Hanafi MM, Rafii MY, Muhammad K. 2012. A quick DNA extraction protocol: Without liquid nitrogen in ambient temperature. Afr J Biotechnol 11 (27): 6956-6964.

Hamalton T. 2016. Wood DNA. Van Sangyan 3 (9): 10-13.

Hamilton MB. 1999. Four primer pairs for the amplification of chloroplast intergenic regions with intraspecific variation. Mol Ecol 8 (3): 521523.

Hussin MC, Kasim J, Yusoff NF, Jasmi NF, Misfar SN. 2014. Effects of tree portion and distance from pith on the basic density, fiber properties and chemical composition of Albizia falcataria wood. Intl J Latest Res Sci Tech 3 (6): 187-191.

Jiao L, Yin Y, Xiao F, Sun Q, Song K, Jiang X. 2012. Comparative Analysis of two DNA Extraction Protocols from Fresh and Dried wood of Cunninghamia lanceolata (Taxodiaceae). IAWA J 33 (4): 441-456. DOI: 10.1163/22941932-90000106.

Piccolo SL, Alfonzo A, Conigliaro G, Moschetti G, Burruano S, Barone A. 2012. A simple and rapid DNA extraction method from leaves of grapevine suitable for polymerase chain reaction analysis. Afr $\mathbf{J}$ Biotechnol 11 (45): 10305-10309.

Porebski S, Bailey LG, Baum BR. 1997. Modification of a CTAB DNA extraction protocol for plants containing high polysaccharide and polyphenol components. Plant Mol Biol Rep 15 (1): 8-15.

Rachmayanti Y, Leinemann L, Gailing O, Finkeldey R. 2006. Extraction, amplification and characterization of wood DNA from Dipterocarpaceae. Plant Mol Biol Rep 24: 45-55.

Rachmayanti Y, Leinemann L, Gailing O, Finkeldey R. 2009. DNA from processed and unprocessed wood: Factors influencing the isolation success. Forensic Sci Intl Genet 3: 185-192.

Sahu SK, Thangaraj M, Kathiresan K. 2012. DNA extraction protocol for plants with high levels of secondary metabolites and polysaccharides without using liquid nitrogen and phenol. ISRN Mol Biol vol 2012. DOI: $10.5402 / 2012 / 205049$.

Shabrina H, Siregar UJ. 2015. Comparison of DNA isolation protocols from Sengon (Falcataria moluccana Miq.) leaves. Proceeding of International Seminar on Tropical Natural resources. Universitas Mataram, Mataram, 10-13 Juni 2015. [Indonesia]

Shi R, Panthee DR. 2017. A novel plant DNA extraction method using filter paper-based 96-well spin plate. Planta 246 (3): 579-584.

Siregar UJ, Rachmi A, Massijaya MY, Ishibashi N, Ando K. 2007. Economic analysis of sengon (Paraserianthes falcataria) community forest plantation, a fast-growing species in East Java, Indonesia. For Pol Econ 9: 822-829.

Stiles JI, Lemme C, Sondur S, Morshidi B, Mandshart R. 1993. Using randomly amplified polymorphic DNA for evaluating. genetic 
relationships among papaya cultivars. Theor Appl Genet 85 (6-7): 697-701.

Verbylaite R, Beisys P, Rimas V, Kuusiene S. 2010. Comparison of ten DNA extraction protocols from wood of European Aspen (Populus tremula L.). Balt For 16 (1): 35-42.
Weising K, Nybom H, Wolff K, Kahl G. 2005. DNA Fingerprinting in Plants. CRC Press, Boca Raton, FL.

Welsh J, McClelland M. 1990. Fingerprinting genomes using PCR with arbitrary primers. Nucl Acid Res 18 (24): 7213-7218. 